\title{
Parliament and Foreign Policy-Making Process
}

\author{
Mohammed Salman Tayie ${ }^{1} \&$ Ibrahim Mohammad Dashti ${ }^{1}$ \\ ${ }^{1}$ Faculty of Economics and Political Science, Cairo University \\ Correspondence: Ibrahim Mohammad Dashti. E-mail: abrahimdashtii@hotmail.com
}

Received: December 17, 2017

Accepted: January 11, $2018 \quad$ Online Published: January 29, 2018

doi:10.5539/ass.v14n2p165

URL: https://doi.org/10.5539/ass.v14n2p165

\begin{abstract}
Objective: The study discusses the role of the parliament in foreign policy-making. The role of the parliament has increased over time in light of the complexities and intertwined interests among countries and the emergence of globalization phenomenon, which has dehumanized the nature and reality of international relations, the need to deepen cooperation among the parliamentarians of countries has increased and expanding it to various fields, and hence emerged the role of parliament in foreign policy-making, so that Public Diplomacy is a substitute for government diplomacy.

Method: The study is based on the institutional approach, which is one of the oldest methods used in political analysis. It stems from the study of political institutions in terms of composition and competencies. The institutional approach in its origins is due to the traditional constitutional school in the study of political systems, which was confusing the concept of state and the political system, and the latter is seen as the system of government as defined by constitutional law, i.e. the set of rules and laws governing public authorities and defining their terms of reference and functions.

Results: The study concluded that parliamentary diplomacy has become a substitute for the official diplomacy and contributes side by side to the exclusion of war crises and finding the pursuit peaceful diplomatic solutions. The Public Diplomacy is a tributary of support for official diplomacy if coordinated together and the value of Public Diplomacy increases as the goals and orientations of the country's foreign policy express the values and aspirations of the people truthfully.

Conclusion: The study concluded that parliaments - especially in democratic systems - play an important role in the process of foreign policy-making, and that there are external and internal factors affecting the effectiveness of the role of parliament in foreign policy. The Kuwaiti parliamentary experience reflected this development of parliamentary diplomacy and its role in foreign policy-making.
\end{abstract}

\section{Introduction}

The parliament is one of the main elements in the analysis of political systems. Parliament is the institution that expresses the will of the people as it consists of elected representatives. It acts as the legislator, issuing laws regulating state and society affairs, and supervising the performance of the Executive Authority. (Al-Din, 1999). The Parliament, with its various names such as the People's Assembly, Nation Assembly, the House of Representatives and the Constituency Assembly, is the legislative entity that represents the legislative authority of democratic states. Parliament came into existence following the revolutions of Europe in the $18^{\text {th }}$ century to limit the absolute power of kings. The Parliament is concerned with all the practices of the legislative authority according to the system of separation of powers. The Parliament shall have full authority with respect to the promulgation of legislation and laws, the approval of budgets, the monitoring of the activities of executive authority (AlKayyali et al., 1991) and ratification of international agreements concluded by representatives of the executive authority. The parliament emerged in the Arab countries in the context of large social and economic transformations and then its role was supported with the rise of the middle class during the transition to the period of the industrial revolution. The main motive for the establishment of the parliament was to represent these forces to have an impact on political life. In developing countries, building the nation state and ensuring common national identity of the sons of one state are additional impetus for the establishment of parliaments (Mukhlaf, 2008). The research problem stems from the assumption that the role of parliaments in general in making and implementation of foreign policy varies from country to another, according to several criteria, including the nature of the political system itself and the political, social, economic and cultural environment in which the parliament operates, in addition to the place of the parliament in the political system and its 
relationship with other authorities, especially the executive authority. This study seek to know the role parliament plays in foreign policy-making, and does the constitutional and legislative framework of the States give a role to parliaments that can enable them to play their role in foreign policy-making through legislative, supervisory and financial mechanisms (Alhajiri, 2007). The study sheds light on the role of parliaments in foreign policy-making, and to what extent their role is compatible with the people's desires and to be a factor in the rapprochement between countries or it will be a stress factor? Is the space of transparency it gives to the public opinion and the media is sufficient to support their positions and orientations in foreign policy, and does it give them an increasing and growing role in the future in foreign policy-making?. Based on the above, the problem of the study is determined in the analysis and interpretation of the nature and characteristics of the role played by parliament in foreign policy, and the factors affecting this role, which may be supportive or obstructive.

\section{Research Methodology}

This study is based on the institutional approach, which is one of the oldest methods used in political analysis. It stems from the study of political institutions in terms of composition and competencies. The origin of the institutional approach came from the traditional constitutional school in the study of political systems (Shalabi, 1996). It confused the concept of the state and the political system, and regarded the latter as a government system as defined by constitutional law, i.e., the set of rules and laws that regulate public authorities and define their powers and functions. (Selim, 2001; Elmenoufy, 1984).

Our study is divided into three axes aimed at analyzing the role of Parliament in foreign policy-making:

First: Conceptual and Theoretical Frame

Second: Parliament and Foreign Policy

Third: Parliamentary Diplomacy and Its Role In Foreign Policy-Making

First: Theoretical and Methodological Frame

\section{Concepts}

\section{The Concept of Legislative Institution:}

The institution is the rules and procedures - formally or informally - but does not define the social, economic and political relations of those who are affected by it (Leftwich, 2006) and is defined as a group with a goal or a set of goals and at least with a specific structure (Furseth \& Repstad, 2006). The legislative institution is the institution that sets the general and abstract legal rules that apply to all individuals (Zaki, 1984). This authority is based on a people-elected entity that is the parliament and exercises legislative authority according to the rules specified in the constitution. This entity was given additional work, including the authority to approve the state budget, the ratification of treaties and the control of the executive authority. (Aldebs, 2010) The functions of parliament are divided into two functions:

\subsection{Legislative Function:}

The legislative function is one of the most important functions of parliaments historically and politically until it became the synonym for the parliament. This function is what makes parliament the most important authority of the state as the representative of the nation, and it is the entity that legislates, modifies and approves laws, and its approval is necessary for all projects and laws submitted by the executive authority. The implementation of executive policy usually depends on the confidence of parliament (Strong, 2015).

\subsection{Control Function:}

Parliament's control over the executive authority is one of the oldest functions of the parliament. It is responsible for following up and evaluating the government's actions according to the principle of separation of powers with a balance between the authorities so as not to impose any authority on the other. Parliamentary control is a means of protecting the interests of people and preventing deviation and adherence to the policies approved by the Parliament (Nayef et al., 2006). Parliaments play an important role in determining budgets for important foreign policy ministries and institutions concerned with foreign policy. Through these budgets, they have an indirect role in foreign policy. It can approve the budget and can suspend it.

\section{The Concept of Foreign Policy}

The process of defining a clear and comprehensive definition of the foreign policy concept has been linked to the various schools that form the field of political science. Therefore, there are many definitions that dealt with the concept of foreign policy. Some people see this concept in terms of interest. James Rosenau sees foreign policy 
as a set of orientations dictated by the historical experience, values and perceptions that characterize the strategic circumstances of the state in international politics, rooted in the great traditions and great aspirations of societies, and intersecting with the set of external commitments (James 1992). Mohamed Alsayed Sleem defines foreign policy as the public program of action chosen by the official representatives of the international unit from the range of alternatives available to achieve specific objectives in the external environment (Sleem, 1994). Or the conduct of the State towards its external environment, whether it is a State or other units in the international environment such as international organizations or attitudes towards a specific issue (Nassif, 1975)

\section{Theoretical Framework}

\subsection{Role Theory}

Role theory is one of the most widely used theories. (Metwally et al., 1999). The emergence of this approach refer back to the field of social science and anthropology, where the beginning of its emergence was by focusing on the study of the behavior of individual itself as the determinant of the group behavior, by perceiving that human is performing roles within the community (Aljohary, 2014). The approach of the role was moved to study the foreign policy and international relations by Kal Holsti in his article "Perceptions of the National Role in the Study of Foreign Policy" in which he focused on communication among citizens, he believed that there is a set of concepts that can be used in foreign policy-making, namely "role performance" which including the trends, decisions and actions taken by governments to implement their national role, that is stemming from the internal and external environment (Speer, 2015).

\subsection{Role characteristics:}

When the concept of role is linked to the conduct of national units, it has several characteristics:

- Role is part of an interactive relationship, which does not exist without gaining its identity from interactive, complementary or reciprocal relationships with other roles and thus gives the role its meaning and function.

- The role has a strong element of legitimacy. William Graham believes that standards make everything legitimate. (Nisbet et al., 1990)

Second: Parliament and foreign policy: -

The powers of the Legislative Authority in domestic matters are more than those of external affairs, due to the secrecy of foreign affairs. The power of the legislative Authority in each country depends on the powers conferred upon it by the constitution. In the United States of America, the legislative Authority is one of the strongest legislative powers in the world for the broad powers granted by the US Constitution to Congress as Senate approval by a majority on the foreign treaties proposed by the president, (US Governance System, US Department of State) and the approval of the president's appointments of ambassadors and officials in foreign affairs. Although the constitution makes the president the supreme commander of the armed forces, it also has the right to declare war. The president had the right to send US Forces to anywhere to protect US national security, but since the Vietnam War, the president has lost that right and has been forced to take congressional approval to send US Forces abroad and to supply any country with weapons worth more than $\$ 50$ million. (Gregorian, 1984; Lindsay \& Ripley, 1992).

Congress has the authority to establish government departments. It has established the Ministry of Foreign Affairs, the National Security Council and all branches of the armed forces and other agencies related to foreign policy. Congress also has the authority to approve the government's proposed general budget, including the defense budget and foreign aid (Tumer, 1974; Manley, 1970).

In Britain, the role of the Legislative Authority in parliament is very limited specially in the external field. Parliament's power is to discuss the government. It exercises this authority in such a strong exercise. The main responsibility in this is on the House of Commons (Epstein, 1996: 90).

In Germany, parliament is briefed on all the files the federal government is negotiating with the EU. The Parliament is obliged to examine these issues in depth and take actions on them (Leyton-Brown, 1982/1983: 59-76; Sondhi, 149-152).

Within the Legislative Authority, there are a number of committees, the most important of which is the "Foreign Affairs Committee". This committee usually reviews the foreign government's proposals and recommends to the members of the Authority either approval or rejection. The Chairman of the Foreign Affairs Committee of the Democratic States plays a role not less than that of the Foreign Minister. On the basis of his conviction and the power of his influence, whether in the committee or the legislative authority, the passage of the government's proposals on foreign policy is stopped (Rabie, 1993). 
In the opinion of Mr. Astrid Ebe of the European Law Foundation affiliated to the University of Freeport, the need to give the parliament more powers in foreign policy and inform experts that the experiences of EU member states have proved the importance of maintaining a strong role of parliaments in determining their foreign policies, particularly those relating to the policy of the Union (Malamud \& Stavridis, 2011).

Third: parliamentary diplomacy and its role in foreign policy-making:

The means and tools of foreign policy vary widely and are used by countries to implement their objectives in the external environment regionally and globally and carried out by both the executive and legislative authority, but is closer to the executive authority than the legislative and most of its roles is assigned to the Ministry of Foreign Affairs (Georges Nouulas, 22 October 2011). But with the spread of democracies and the growing role of parliament in foreign policy, offset by the growing negativity of executive authority practices for its role in the foreign ministry, the Legislative Authority was granted more space in the process of foreign policy-making at the expense of the executive authority (Svensson, 1988). The proximity of public diplomacy to public opinion has given it popular support in its growing role in foreign policy-making (GÖTZ, 2005; Nzewi, 2014).

\section{Tools for Implementing Foreign Policy}

States use several tools to achieve their foreign policy objectives:

\subsection{Intelligence}

Foreign policy decision makers need to have the necessary information, especially confidential information, which is not available to specialists and diplomatic bodies abroad, so the intelligence service is used to collect this information in a confidential manner. (Ki Lawson: 452)

\subsection{Armed Forces}

The armed forces are one of the main means of implementing foreign policy, and one of the essential elements of the success of diplomacy and that the negotiation of the status of power strengthens the diplomatic position of the state, since the force prevents granting or giving concessions that harm the vital interests of the state if it is under pressure and threats that it can not resist. (Frankel, 1990).

\subsection{Propaganda}

Propaganda means any systematic attempt to influence the minds, emotions and behavior of a particular group in order to achieve a specific general purpose and to be directed to the peoples of other States, not to their Governments (Hamza, 1968).

\subsection{Economic Tools}

Emerged as an important tool for international political engagement in the post-World War II era, surpassing the standards of effectiveness and influence on traditional strategic means. (Barnhart, 1987). Economic tools have taken a prominent place in the foreign policy-making. Economic tools take several forms such as tariffs, monetary restrictions, economic embargoes, economic boycotts, economic integration, freezing of assets, aid and economic grants. (McNaugh, 1954; JAMES, 1980)

\subsection{Diplomacy}

This term spread after the conference in Vienna in 1815, where the emergence of distinguished diplomatic cadres in the government, and spread the phenomenon of permanent and resident diplomatic representation. (Muhammad Rabie and others, 1993: 1089-1090). The concept evolves over time and means in the modern era the management of foreign affairs of the state and the care of citizens and the management of international relations and the reconciliation of the interests of nations under international laws and treaties, and seek to resolve differences between them in peaceful ways to remove the threat of armed conflict.

The most comprehensive and precise definition is the definition by Philip Kaye that diplomacy is "the means by which a person of international law use to conduct foreign affairs by peaceful means, especially through negotiation" (Alkayali \& Ehren, 1991) Diplomacy is a mode of action in which the State chooses the most appropriate means of communication in order to achieve the objectives of foreign States. Diplomacy is the process of representation and negotiation among nations in the conduct of their international relations (Ghaly et al., 1979), defined by the American diplomat John Kennan as "the process of communication between governments." (Thayer, 1960)

\section{Parliamentary Diplomacy}

The concept of parliamentary diplomacy: 
Parliamentary diplomacy is a special style of open collective diplomacy in which international organizations take their place. Parliamentary diplomacy with congressional diplomacy has many characteristics, most notably pluralism and publicity, but it differs with it as the parliamentary diplomacy follows strict procedural rules. (Rabie, 1993).

Globalization has reduced the humanitarian character of the nature and reality of international relations and has helped to move from the concept of parliamentary cooperation to parliamentary diplomacy, which has become a means of promoting cooperation among nations. Members of Parliament explain and clarify the official positions of their countries to other members of parliaments. Parliamentary diplomacy reflects the trend that affirms that the internal democracy of nations is linked to the democratization of relations between nations and therefore occupies a great deal of space in the field of international relations, which some consider complementary diplomacy and accompaniment of the governmental diplomatic activity (Johnson, January 24, 2013)

Parliamentary diplomacy can be seen also in an active way in the meetings of geopolitical groups among its members first and then with others. As negotiation, interaction and persuasion play a significant role in diplomatic parliamentary activity to reach consensus. The formulation of any resolution or recommendation requires discussions and negotiations between many concerned parties (Amani, 2016).

Diplomacy is science and art; it is aimed at achieving the interests of the State at the external level, and diplomacy is a science because it is rely on international laws and norms. Diplomacy is an art because it requires courteousness and fluency in dealing with the files presented (Baghora, April 2012).

Public diplomacy has taken a prominent place in the arena of international relations because of technological advances in communications. With the spread of culture and increased political awareness, domestic and international opinion has become an important factor in guiding the foreign policies of countries. Public opinion played an influential role in resolving many issues (Algendy, 1998).

Public diplomacy has played an important role in the international arena under the new world order, as parliaments reflect the expression of the wishes of the people and the trends of public opinion within the country, giving it international strength and effectiveness at the international level. (Ibrahim, 2010: 27).

Public diplomacy is one of the distinguishing features in the history of contemporary international relations in terms of flexibility and dynamism and its growing influence on all levels. (Algendy, 1998: 21). Perhaps the most important characteristic of public diplomacy is that it can't be done between accredited representatives of states or between negotiators committed to the views of their governments, but between parties who do not hold official credentials and do not have the status of sovereignty, but they represent different political forces representing broad trends of public opinion. (Ibrahim, 2010: 31).

The applications of public diplomacy are varied and may fall into the form of international contacts by a public figure whose position may exceed the borders of the state or through organized popular movements such as political parties, organizations, federations and associations. These movements may be coordinated among themselves within a regional or continental regulatory framework or international for further interaction.

People's diplomacy is influenced by various means, such as holding conferences, seminars, dialogues, festivals, visits and delegations. Although these meetings are consultative and often end with recommendations that are not binding, they are considered as important platforms for addressing public opinion to make their work public and transparent.

Public diplomacy is seen as a tributary of support for official diplomacy if coordinated. The value of popular diplomacy increases as the goals and orientations of the country's foreign policy truthfully express the values and aspirations of peoples. (Ibrahim, 2010: 31).

Parliamentary diplomacy is the most popular type of diplomacy, which is exercised by parliamentarians and parliaments and may take the form of conferences, bilateral meetings or more, meetings or others. Parliamentary diplomacy is characterized from other forms of public diplomacy where its parties enjoy a moral and legal mandate as they are elected and representing their people and feel their wishes (Munira, 2009).

The rapid and changing developments in international relations have had a great impact on the internal affairs of the countries and have been reflected in the nature of their social life, especially after the growth of trade exchanges between countries. This situation has forced the national parliaments to intervene in the international arena in order to contribute to international efforts in order to achieve peace, democracy and development, which are of international importance that will prompt parliamentarians to cooperate with the parliamentarians of other States in such fields as human rights, environment, development and economy (Grimmest, June 1, 1999). 
Parliamentary diplomacy has been engaged early in an international organization that coordinates its efforts and supports the bonds of friendship between parliamentarians, brings their views closer to various international issues and promotes cooperation among peoples. The Inter-Parliamentary Union was founded in 1889, followed by parliamentary associations and organizations. (Munira, 2009).

One of the most prominent problems facing the concept of parliamentary diplomacy is that there is a team that considers official diplomacy to be the only channel of foreign policy, while the other emphasizes that there is no contradiction between official diplomacy and parliamentary diplomacy, because parliamentary diplomacy expresses official positions recognized internationally, Many views give parliamentary diplomacy special importance at the international level as an engine and complementarity of foreign policy and give it a bit of privacy, and confirms such views that official diplomacy and parliamentary diplomacy can not conflict in attitudes or ignoring opinions or competing in goals and interests.

Another problem in the frame of the same subject is that the parliamentary system in many countries is based on duality. In other words, there are two parliamentary chambers: a first chamber, a popular council with a national dimension, consisting of deputies all elected by secret free and direct ballot by the people, the second chamber, two thirds of which are elected members at the level of the previously elected local councils and the other third are appointed by the highest authority in the country represented by the governor. In this duality, political trends may not be compatible; therefore, the positions expressed by some international issues differ. The supporters of the monopoly of official diplomacy for external activity also pose a third problem which is not ensure the presence of deputies in a state of official activity throughout the year is not guaranteed as the parliament holds two parliamentary sessions a year and other parliaments holding one session a year and enjoy a long leave of four months, such as the Kuwaiti parliament.

Whatever the differences in opinions, parliamentary diplomacy in general remains an effective tool, with many events and experiences proving its ability to strengthen the activity of States in order to serve peoples in peace, democracy, security and development.

\section{The advantages and disadvantages of parliamentary diplomacy:}

It is normal for each country to have strategic goals, internal and external national interests and the means used to achieve its objectives. In this way, many countries are mobilizing all their available means and methods, including institutionalization and representation in the service of its path, including the elected councils, considering that foreign policy is a mirror of internal politics. (Rabie, 1993).

\section{Advantages of Parliamentary Diplomacy:}

Parliamentary diplomacy is characterized by several main characteristics, including the following:

1. Pluralism: These are the symbol of the number of participants in parliamentary diplomacy and the multiplicity and overlap of issues on the agenda and work program, the number of participants means the multiplicity of interests and overlapping and sometimes conflicting. (Barakat et al., 1996). The success of diplomacy is inversely related to the extent to which the interests of the States involved in the negotiation process differ, as well as the multiplicity of issues for consideration, which has a profound impact on the positions of States on a case-by-case basis, because the degree of interest of States in the issues is not the same, thus, the multiplicity of participants in the negotiating process and the multiplicity of issues for negotiation leads to the division of States into groups, which makes the negotiation process a very difficult task because it is between collective parties, and as a result of that, it gives the settlement a form of weakness shape that negatively affect the effectiveness at the time of implementation (Mohammad Rabie, 1993: 1091)

2. Publicity: This is a feature associated with parliamentary diplomatic activity. It is often preceded or accompanied by extensive media statements that are very provocative, which may be ideological and public in nature, and are related to the importance of informing public opinion of the need to accept consensus solutions in settling international issues. Parliamentary diplomacy may, however, take another approach: to combine public debates and private side negotiations, called "backstage diplomacy" or "quiet diplomacy", which combine by continuous interaction with negotiation method (Mann, 1999).

\section{Disadvantages of Parliamentary Diplomacy:}

Despite the various advantages of parliamentary diplomacy, international relations experts attributed the following drawbacks to it (Rabie, 1993):

1. Parliamentary diplomacy puts governments under direct pressure in front of public opinion, especially in 
the negotiation stage, which embarrasses it and may force them to take emotional positions to satisfy public opinion.

2. Parliamentary diplomacy helps to fragment the opinion on the problems between the majority of a particular trend and a minority of the other trend, and this kind of disagreement keeps the problems without solutions.

3. Parliamentary diplomacy called by its opponents "diplomacy of sound amplifiers" based on libel and charges.

Some experts on international relations respond to these criticisms with the following points:

1. The main task of diplomacy is to defend the vital interests of peoples. Hence, the subordination of diplomatic work to popular control is a positive phenomenon.

2. Ensuring freedom for the press, opposition parties and public opinion when discussing the terms of the treaties to which their states are parties is to be persuaded to justify them and to accept them for their obligations (Rabie, 1993). These discussions help to redraft the content of these treaty obligations that are consistent with the national interest.

\section{Conclusion}

The role of parliament is increasing in the foreign policy-making, and the nature of the work of parliament differ from one state to another, according to the constitutional framework and the distribution of competencies between the authorities, in addition to the extent of democratic development and the strength of parliament and the capabilities of its members. All of these factors contribute to the size of the parliament's role in foreign policy-making.

States use several means to achieve their foreign policy objectives. Perhaps the most important of these is parliamentary diplomacy. Since parliaments are representative of the peoples, they aspire to have a significant and effective role in the rapprochement between peoples. Parliamentary efforts are important in deepening cooperation between parliamentarians and pushing the peace process, And to remove the specter of conflict and war. The bet is that Parliament plays a role in influencing foreign policymakers and decision-making centers by virtue of the independence of Parliament Members and the margin of broad activity available to them.

In light of the complexity and interrelatedness of the interests among countries, the emergence of globalization and the dehumanization of the nature and reality of international relations, there is a need to deepen the cooperation between the parliamentarians of countries and to expand their fields and expand them to various fields. Hence the concept of "parliamentary cooperation" have contributed to the consolidation of joint efforts in a framework of consultation and coordination in order to bring political, cultural, economic and social approaches closer to the international level.

Public diplomacy has taken a prominent place in the arena of international relations and has played an important role in the international arena under the new world order, as parliaments reflect the expression of people desires and the trends of public opinion within the country, giving it international strength and effectiveness at the international level.

The value of public diplomacy increases as the goals and orientations of the State's foreign policy are truthfully expressed about the values and aspirations of peoples.

The Kuwaiti parliament has played a supportive role in Kuwait's affairs since the beginning of the Constituent Assembly and its role in dealing with the Iraqi claims in Kuwait, through the Iraqi invasion of Kuwait in 1990 and the demarcation of the Kuwaiti-Iraqi borders in 1993. Diplomacy Parliament became a part of Kuwait's foreign policy.

\section{References}

Al-Hajri, A. H. M. (2007). Financial Competencies of the Kuwaiti National Assembly (Unpublished Doctoral Thesis, Menoufia University: Faculty of Law).

Almunufi, K. (1984). Introduction to the Methods and Means of Research in Political Science (Cairo: Dar Al-Gharib for Printing, Publishing and Distribution).

Al-Mutairi, N. (2006). The National Assembly and its Role in Parliamentary Diplomacy. National Assembly.

Almuthaqaf Electronic Journal. Sobha Baghoura, 9 April 2012, issue 2085.

Al-Qasabi, A. (2006). Research Methods in Political Science. Egypt: Cairo University, I, 2. 
Al-Qubaisi, H. (2008). American Foreign Policy between Two Schools: The New and Realistic School. Beirut: Arab Science House, 1.

Aspartopan, V. (1996). The Soviet Foreign Policy...in the Foreign Policy Approach in the Countries of the World. Translated by Hassan Saab. Beirut: Dar l-Kuttab.

Barakat, N. et al. (1989). Principles of Political Science. Saudi Arabia: King Saud University.

Debs, E. (2010). Political Systems. Amman: Culture House.

El-Gohary, M. S. The role of political leadership in the process of political reform in Azerbaijan 2003-2013. https://democraticac.de

Frankel, J. International Relations. Translated by Ghazi Al-Kasabi. Cairo: Egyptian Modern Office.

Ghaly, B., \& Issa, M. (1979). Introduction to Political Science. Cairo: The Anglo-Egyptian Library.

Ghassan, E.-G. (1998). Multilateral Diplomacy, Law of International Organizations. Jordan Diplomatic Institute.

Hamad, M. (2002). The Relationship between the Legislative and Executive Authority in the American Political System. Unpublished MA Thesis. Cairo University: Faculty of Economics and Political Science.

Hamza, A. L. (1968). Media and Propaganda. Baghdad: Al Ma'arif Press.

Ibraheem, I. A. Y. The Role of the Unified Arab Parliament in Activating Joint Arab Action (Unpublished MA Thesis, Cairo: Faculty of Economics and Political Science).

Kayali, A. W. et al. (1991). Encyclopedia of Politics. Lebanon: The Arab Institution for Studies and Publication.

Lawson, K. Political Society: A Comparative Introduction to Political Science. Translated by Masoumah Habib.

Massoud, A. (2016). The Role of Parliament in Foreign Policy Making.

Metwally. M. S., \& Abdelmeguid, H. S. (1999). Social Guidance: Theoretical Principle and Scientific Applications. Dubai: Dar Al-Qalam Publishing.

Michel, M. (1999). Encyclopedia of Social Sciences, translated by Adel Mokhtar Al-Hawari and Saad Abdulaziz Musloh (1st ed.). Alexandria: Dar Al-Maarifa Al-Jami'a.

Mounira, M. (2009). The Role of Informal Diplomacy in the Implementation of Foreign Policy (Unpublished MA Thesis, Introduction to the University of Constantine, Algeria).

Nisbet, R. et al. (1990). Sociology, translated by Grace Khoury. Beirut: Dar Al-Nidal.

Rabea, M. M. et al. (1993). Encyclopedia of Political Science. Kuwait: Kuwait University.

Ralon, E. (1996). British Foreign Policy in Foreign Policy Approaches in the Countries of the World. Translated by Hassan Saab, Beirut: Dar Al-Kitab Al-Arabi.

Samurai, Q. M. (2008). Mechanisms of Political Systems in Political Decision-Making. Al-Sarmazi Mag., 4(10).

Selim, M. E. S. (2001). Foreign Policy Analysis (2nd ed.). Beirut: Dar El Geel, Second Edition.

Selim, M. E. S. (Ed.) (1994). The New World Order. Cairo: Center for Research and Political Studies.

Selim, M. E. S. Interpretation of Foreign Policy. Saudi Arabia, King Saud University.

Shalaby, M. (1996). Methodology in Political Analysis: Concepts, Approaches and Tools. Cairo: Publishing House for Universities.

Shatta. A. A. (2003). Theory of Role and the Virtual Perspective of Sociology. Cairo: Egyptian Library for Publishing and Distribution.

Taj Al-Din, A. S. Political Encyclopedia. www.sis.gov.eg

Thayer, C. (1960). Diplomat. Translated by Khairi Hammad. Beirut: Dar Al-Talayah for printing.

US Government System, US Department of State

Zaki, B. A. (1984). Dictionary of Administrative Terms. Cairo: Dar Al-Hadaba.

\section{Copyrights}

Copyright for this article is retained by the author(s), with first publication rights granted to the journal.

This is an open-access article distributed under the terms and conditions of the Creative Commons Attribution license (http://creativecommons.org/licenses/by/4.0/). 